\title{
TEMPOROMANDIBULAR JOINT IN ADULT RHEUMATOID ARTHRITIS* A COMPARATIVE EVALUATION OF 100 CASES
}

BY

\author{
A. S. T. FRANKS \\ Department of Dental Prosthetics, University of Birmingham Dental School
}

As emphasized by Uotila (1964), medical interest in the stomatognathic system of patients with rheumatoid arthritis has been mainly concerned with the theories of focal infection. In recent years these concepts have become less commonly accepted and the interest accordingly reduced. However, the temporomandibular joints may be considered amongst the more important of the body and a practical clinical consideration of their reaction to systemic disease is an obvious requirement.

The knowledge that rheumatoid arthritis affects the temporomandibular joint has been on record for a number of years, but the reported incidence of manifestations in this joint vary greatly in the literature (Table I). The majority of previous studies have dealt with relatively small numbers of patients.

TABLE I

REPORTED INCIDENCE OF TEMPOROMANDIBULAR JOINT INVOLVEMENT IN RHEUMATOID ARTHRITIS

\begin{tabular}{l|c|c}
\hline \multicolumn{1}{c|}{ Author } & Date & Incidence per cent. \\
\hline Ragan & 1949 & $4 \cdot 7$ \\
Markowitz and Gerry & 1949 & $8 \cdot 7$ \\
Hankey & 1963 & 10 \\
Hartfall and Wright & 1961 & 19 \\
Einaudi and Viara & 1964 & $29 \cdot 3$ \\
Mériel, Ruffie, Cadenat, & 1960 & 31 \\
Fournié, and Blanc & 1964 & 41 \\
Uotila & 1941 & 51 \\
Russell and Bayles & 1959 & 56 \\
Blanc & 1963 & 70 \\
\hline
\end{tabular}

The present study was designed as a survey of an unselected group of patients with confirmed rheumatoid arthritis to determine the frequency and characteristics of lesions of the temporomandibular joint. Comparison has been made with control groups to evaluate the possible clinical significance of the findings, and with patients complaining of the

*The substance of this article was reported to the Heberden Society on November 12, 1965. "temporo-mandibular joint pain-dysfunction syndrome" as previously investigated and described (Franks, 1964).

\section{Method}

The hundred unselected patients in this study were attending the day clinic at the Arthur Stanley Institute for Rheumatic Diseases, London, and had been confirmed as cases of rheumatoid arthritis. After an interview to a standard questionaire, the temporomandibular joints and their environment, which includes the oral cavity, were examined by the author. Assessment of the general index of rheumatoid arthritis was undertaken by a rheumatologist (Dr. B. Watkin).

Radiological assessment was made by standard lateral oblique film. Where doubt existed, that is there was positive clinical evidence but negative radiological findings, tomograms were taken of the temporomandibular joints.

When the age-sex distribution of the patients was known-at the termination of the study - three control groups of 100 randomly selected patients were formed matched for age and sex with the rheumatoid group.

$$
\begin{aligned}
& \text { Control Group " } A \text { "- } \text { a hundred selected from } 590 \\
& \text { non-regular attenders for dental } \\
& \text { treatment (i.e. less than twice a } \\
& \text { year). }
\end{aligned}
$$

The data were analysed for degrees of significance using the $\chi^{2}$ test. 


\section{Age-Sex Distribution}

\section{Results}

The male : female ratio of the patients examined was just under $1: 3$. The age range of both sexes was comparable (Fig. 1). No patient was under the age of 25 and the majority were over 55.

\section{Temporomandibular Joints}

Some history of temporomandibular joint disorder (i.e. pain, noise within the joint or movement, altered function of the joint) was discovered in 53 per cent. of the rheumatoid group. No patient could antedate this local complaint before their other joint symptoms. Clinically 40 per cent. of the rheumatoid patients had palpation tenderness of the temporomandibular joints, and 63 per cent. had crepitus in at least one of the moving jaw joints. These results are displayed with the appropriate control figures in Table II.

From Table III it can be seen that patients with a history of temporomandibular joint disorder were more likely to have crepitus and change in the temporomandibular joints. However, the history was of no significance in relation to the radiological findings, which disclosed that 56 per cent. had structural changes of the calcified joint tissues. It

TABLE III

HISTORY OF TEMPOROMANDIBULAR JOINT DISORDER RELATED TO JOINT CHANGES IN 100 RHEUMATOID PATIENTS

\begin{tabular}{|c|c|c|c|}
\hline oromandibular & Present & Absent & Total \\
\hline Joint Disorder & 53 & 47 & 100 \\
\hline $\begin{array}{l}\text { Crepitus } \\
\text { Radiological Change }\end{array}$ & $\begin{array}{l}38 \\
31\end{array}$ & $\begin{array}{l}25 \\
25\end{array}$ & $\begin{array}{l}63 \\
56\end{array}$ \\
\hline
\end{tabular}

was found (Table IV) that, where crepitus wasp present in the moving joint, there was a highly sig nificant incidence of radiological positives: 43 out of 63 , as opposed to 13 out of 37 in which crepitus $\overrightarrow{0}$ was absent.

TABLE IV

CREPITUS IN THE JOINT RELATED TO RADIOLOGICAL EVIDENCE OF CHANGE

\begin{tabular}{|c|c|c|c|}
\hline & Crepitus & No. of Cases & $\begin{array}{c}\text { Radiological Change } \\
\text { in Joint }\end{array}$ \\
\hline Present & & 63 & 43 \\
\hline Absent & $\begin{array}{l}\text { History of Joint } \\
\text { Disorder } \\
\text { No History of } \\
\text { Joint Disorder }\end{array}$ & $\left.\begin{array}{l}15 \\
22\end{array}\right\} 37$ & $\left.\begin{array}{l}4 \\
9\end{array}\right\} 13$ \\
\hline \multicolumn{2}{|c|}{ Total Rheumatoid Patients } & 100 & 56 \\
\hline
\end{tabular}

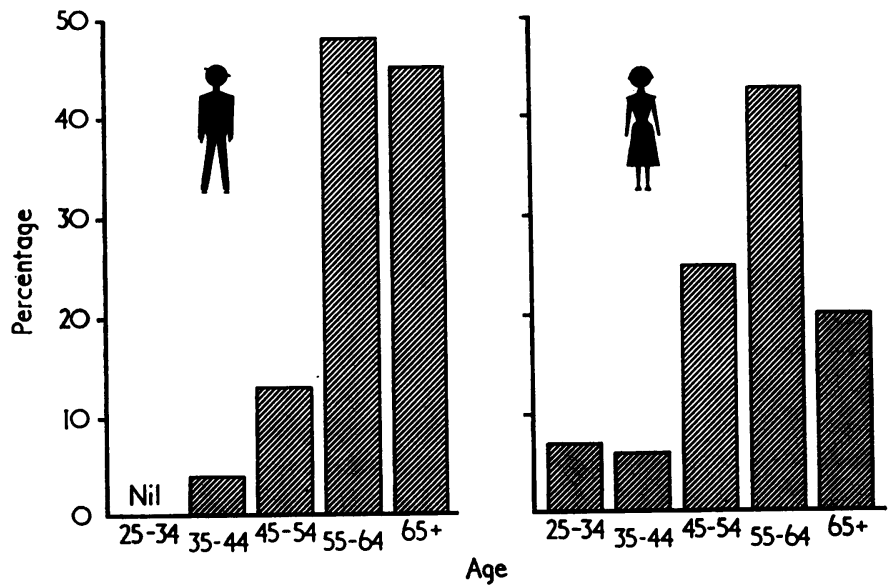

Age

Fig. 1.-Histogram of age range of 100 patients with rheumatoid arthritis.

TABLE II

SIGNS AND SYMPTOMS OF TEMPOROMANDIBULAR JOINT DISORDER IN PATIENTS WITH RHEUMATOID ARTHRITIS AND THREE CONTROL GROUPS

\begin{tabular}{|c|c|c|c|c|}
\hline \multirow{2}{*}{ Group } & \multirow{2}{*}{$\begin{array}{l}100 \\
\text { Patients with } \\
\text { Rheumatoid } \\
\text { Arthritis }\end{array}$} & \multicolumn{3}{|c|}{ Control Groups (100 each) } \\
\hline & & $\mathbf{A}$ & B & C \\
\hline $\begin{array}{l}\text { History of Temporomandibular Joint Disorder } \\
\text { Tenderness of Temporomandibular Joint } \\
\text { (Palpation) } \\
\text { Crepitus in moving Temporomandibular Joint }\end{array}$ & $\begin{array}{l}53 \\
40 \\
63\end{array}$ & $\begin{array}{r}24 \\
0 \\
0\end{array}$ & $\begin{array}{r}19 \\
0 \\
0\end{array}$ & $\begin{array}{r}100 \\
11 \\
4\end{array}$ \\
\hline
\end{tabular}


Some evidence of temporomandibular joint disturbance, clinical or radiographic, was present in 86 per cent. of the rheumatoid patients.

\section{Oral Health}

This was almost uniformly poor, 86 per cent. being dentally unfit.

Only six of the patients attended for regular dental treatment, so that as a group they are directly comparable, in terms of dental health, with Control series A.

However only 51 per cent. of the rheumatoid patients had some natural teeth, and this causes hesitation in comparisons with the control groups in which the proportion was much higher. Particularly is this so if we attempt to consider the possible changes in temporomandibular joint function brought about by partial loss of natural teeth.

However, if one takes this group of 51 per cent. with natural teeth and examines those within it who have temporomandibular joints affected by rheumatism, one finds ninety per cent. with unreplaced missing teeth with an average of eight missing and that this is not significantly different from the control series A (Table V).

Further, if we consider unbalanced tooth lossbetween the two sides of the mouth, the $\chi^{2}$ test again shows no significant difference between the rheumatoid group and Control A. In addition, 57 per cent. of those with natural teeth (i.e. 25 of the 44 rheumatoid patients) had some radiological change, compared with 55 per cent. of those with full dentures (i.e. 23 of the 42 rheumatoid patients with full dentures)-no significant difference. In view of these findings, it was thought justified-in this investigation-to consider the patients with natural and artificial teeth together.

Previous studies of temporomandibular joint disorders at the Institute of Dental Surgery have indicated (Franks, 1967) the apparent aetiological importance of certain functional habits-particularly that associated with unilateral chewing. The importance of this factor appears to be underlined yet again in the disorder under current investigation (Table VI). Here the incidence of the habit amongst the rheumatoid patients with temporomandibular involvement shows a significant relationship.

TABLE VI

CHEWING HABIT RELATED TO INCIDENCE OF RHEUMATOID ARTHRITIS IN TEMPOROMANDIBULAR JOINT

\begin{tabular}{c|c|c|c|c}
\hline Group & $\begin{array}{c}\text { Rheumatoid } \\
\text { Arthritis of } \\
\text { Temporomandibular } \\
\text { Joint }\end{array}$ & A & B & C \\
\hline $\begin{array}{c}\text { Unilateral Chewing } \\
\text { Habit }\end{array}$ & 69 & 50 & 43 & 82 \\
\hline
\end{tabular}

\section{Radiological Findings}

Changes appear to occur first in the anterior margin of the condyle (Fig. 2). Progressively the

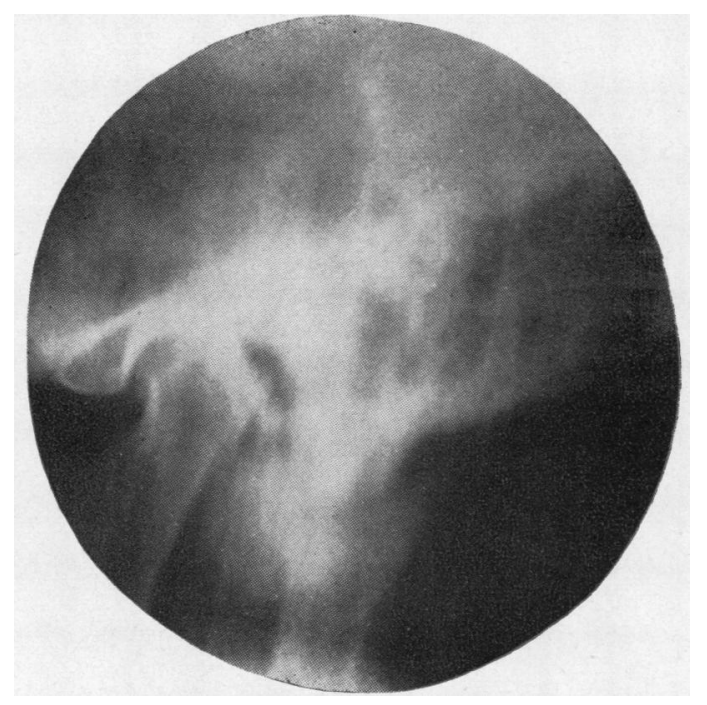

Fig. 2.-Right temporomandibular joint in closed position. Tomogram showing early rheumatoid change. The radiolucent area is seen in the anterior part of the condyle.

TABLE $V$

DENTITION IN 86 PATIENTS WITH RHEUMATOID ARTHRITIS OF THE TEMPOROMANDIBULAR JOINT AND CONTROL GROUPS

\begin{tabular}{|c|c|c|c|c|c|}
\hline & \multirow{2}{*}{ Group } & \multirow{2}{*}{$\begin{array}{c}\text { Rheumatoid } \\
\text { Arthritis of } \\
\text { Temporomandibular } \\
\text { Joint }\end{array}$} & \multicolumn{3}{|c|}{ Controls } \\
\hline & & & $\mathbf{A}$ & B & $\mathbf{C}$ \\
\hline \multirow{4}{*}{ Dentition } & Per cent. with some natural teeth & 51 & 80 & 84 & 92 \\
\hline & Per cent. with unreplaced missing teeth & 90 & 88 & 69 & 76 \\
\hline & $\begin{array}{l}\text { Average number of missing teeth } \\
\text { (per person) }\end{array}$ & 8 & 9 & 7 & 7 \\
\hline & $\begin{array}{l}\text { Per cent. with tooth loss unbalanced } \\
\text { between two sides of mouth }\end{array}$ & 73 & 66 & 52 & 86 \\
\hline
\end{tabular}


destruction causes the condyle to resemble the "sharpened pencil deformity" of the phalanges (Fig. 3) (Simon, 1965). Uotila (1964) suggested its likeness to "the mouth-piece of the flute". In the most severe manifestation the condyle is completely obliterated (Fig. 4), but function may still remain satisfactory; the patient illustrated in Fig. 4 could open his mouth $44 \mathrm{~mm}$. (the normal average) and had in fact no history, no crepitus, no symptoms.

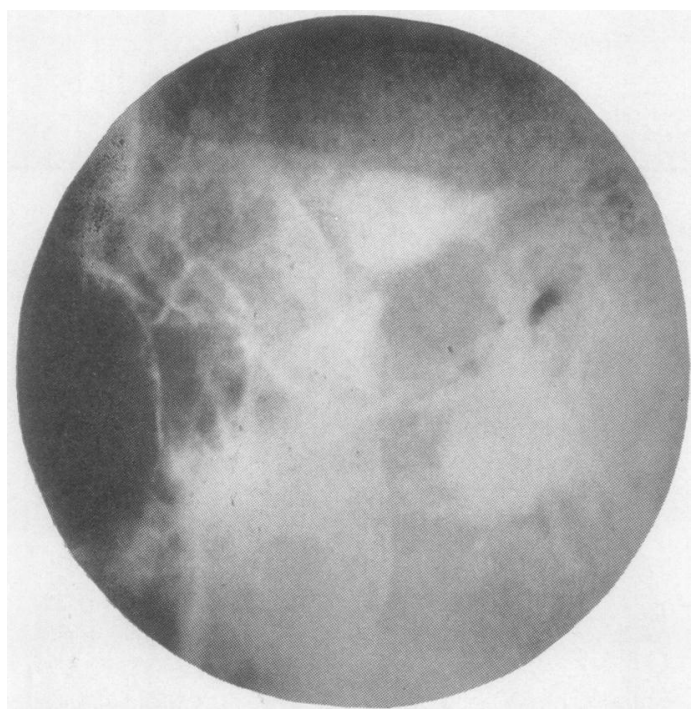

Fig. 3.-Right temporomandibular joint in open position. Standard radiograph showing results of progressive destruction of condyle head, leading to an arp zar ance similar to "the mouth-piece of a flute."

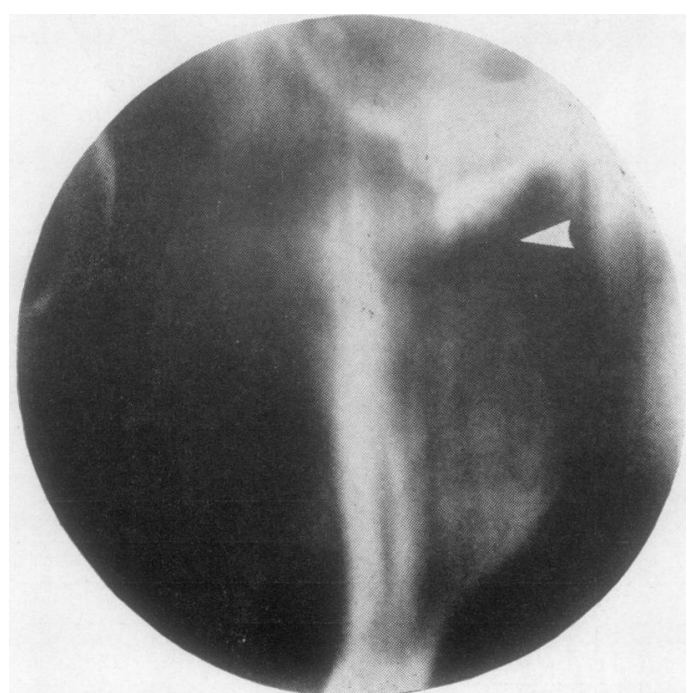

Fig. 4.-Right temporomandibular joint in closed position. Tomogram showing severe destruction of condyle and condylar neck in rheumatoid arthritis. The condyle is completely obliterated.

\section{General Rheumatoid Status}

In each of the rheumatoid patients, the number of joints involved in the arthritic process was listed by Dr. Watkin. Small and large joints were collated? separately (Table VII). 38 per cent. of the group $\overrightarrow{\vec{c}_{\text {p }}}$ with between four and seven small joints affected and 53 per cent. of those with over eight smallo joints affected had involvement of the temporo $\overline{\bar{w}}$. mandibular joints, but the incidence is not significant $\vec{\nabla}$ The number of large joints involved, however, is significant; as the number increases so does thes incidence of temporomandibular trouble.

TABLE VII

RHEUMATOID ARTHRITIS IN TEMPOROMANDIBULAR JOINTS RELATED TO SYSTEMIC JOINT INVOLVEMENT

\begin{tabular}{|c|c|c|}
\hline \multicolumn{2}{|c|}{$\begin{array}{c}\text { Systemic Manifestations of } \\
\text { Rheumatoid Arthritis } \\
\text { (Joints involved) }\end{array}$} & \multirow{2}{*}{$\begin{array}{c}\begin{array}{c}\text { Rheumatoid } \\
\text { Arthritis of } \\
\text { Temporomandibular } \\
\text { Joint (per cent.) }\end{array} \\
0 \\
38 \\
53\end{array}$} \\
\hline Small & $\begin{array}{l}\text { Up to } 3 \\
4-7 \\
\text { Over } 8\end{array}$ & \\
\hline Large & $\begin{array}{l}\text { Up to } 3 \\
4-7 \\
\text { Over } 8\end{array}$ & $\begin{array}{l}35 \\
58 \\
78\end{array}$ \\
\hline
\end{tabular}

Functional incapacity was graded according Steinbrocker, Traeger, and Batterman (194). Table VIII shows that the highest incidence of temporomandibular joint disturbance occurs in theo more severe cases of rheumatoid arthritis. Theळ association of the progressive percentage increase in affection of the temporomandibular joint withô을 increasing functional incapacity is significant in itself. A significant percentage of the patients examined showed only moderate systemic manifestations of rheumatoid arthritis.

TABLE VIII

FUNCTIONAL INCAPACITY OF PATIENTS WITH RHEUMATOID ARTHRITIS OF TEMPOROMANDIBULAR JOINTS

\begin{tabular}{|c|c|c|}
\hline $\begin{array}{c}\text { Functional } \\
\text { Incapacity } \\
\text { (Steinbrocker and } \\
\text { others, } 1949\end{array}$ & $\begin{array}{l}\text { Rheumatoid Patients } \\
\text { Studied (Percentage } \\
\text { incidence within } \\
\text { whole group) }\end{array}$ & $\begin{array}{l}\text { Patients with Rheumatoid } \\
\text { Arthritis of } \\
\text { Temporomandibular Joint } \\
\text { (Percentage incidence } \\
\text { within each } \\
\text { "incapacity group") }\end{array}$ \\
\hline $\begin{array}{l}\text { II } \\
\text { III } \\
\text { IV }\end{array}$ & $\begin{array}{r}4 \\
51 \\
40 \\
5\end{array}$ & $\begin{array}{l}33 \\
41 \\
60 \\
70\end{array}$ \\
\hline
\end{tabular}

Analysis of the age at onset of the rheumatoid $\cong$ condition (Table IX, opposite) and of the erythrocyte sedimentation rate revealed no significant relationship. 
TABLE IX

RELATIONSHIP OF AGE AT ONSET OF RHEUMATOID ARTHRITIS AND LESIONS IN THE TEMPOROMANDIBULAR JOINT (PER CENT.)

\begin{tabular}{c|c|c|c|c|c|c}
\hline Age at Onset (yrs) & $15-24$ & $25-34$ & $35-44$ & $45-54$ & $55-64$ & $65+$ \\
\hline $\begin{array}{c}\text { Rheumatoid } \\
\text { Arthritis of } \\
\text { Temporomandibular } \\
\text { Joint }\end{array}$ & 82 & 71 & 66 & 79 & 33 & 50 \\
\hline
\end{tabular}

Haemoglobin averages (at least five per patient) showed a significantly higher incidence of temporomandibular joint involvement amongst those with a reduced haemoglobin level (Table $\mathrm{X}$ ).

TABLE X

HAEMOGLOBIN LEVELS (AVERAGE OF AT LEAS T 5 ESTIMATIONS PER PATIENT) RELATED TO RHEUMATOID ARTHRITIS OF TEMPOROMANDIBULAR JOINT

\begin{tabular}{c|c}
\hline $\begin{array}{c}\text { Hb } \\
\text { (per cent.) }\end{array}$ & $\begin{array}{c}\text { Rheumatoid Arthritis of } \\
\text { Temporomandibular Joint } \\
\text { (per cent.) }\end{array}$ \\
\hline 80 and over & $\frac{59}{77}$ \\
\hline under 80 & $\frac{5}{27}$ \\
\hline
\end{tabular}

\section{Discussion}

\section{Clinical Findings}

The age-sex distribution of the patients under discussion agrees closely with the average patterns associated with the complaint in the general population (Kellgren, Lawrence, and Aitken-Swan, 1953), so that there is some justification for drawing general conclusions from the results.

Previously published work (Table I) has shown a varying incidence of rheumatoid temporomandibular joints. The study of Blackwood (1963) is of especial importance because it is based on autopsy findings, seven of his cases of rheumatoid arthritis demonstrated temporomandibular joint changes, and although the group is small his results are the most objective.

A question which requires further evaluation is whether the incidence of temporomandibular joint disorder is increasing. A comparable suggestion has been made for the hip joint (Edström, 1961), the explanation being based on an osteoporosis following the use of steroids and the resultant abuse of damaged joints freed from pain.

In dealing with disease of the temporomandibular joint, it is important to be aware of the diagnostic problems associated with it (Franks, 1964) and the almost epidemic nature of non-destructive temporomandibular joint dysfunction (Table III). The control studies disclosed an incidence of 24 and 19 per cent. in the two groups.
Certain differential characteristics of the rheumatoid temporomandibular joint are clearly shown by the results of the study. Tenderness is significantly more frequent over the rheumatoid joint, but in the dysfunction cases the masticatory muscles are more frequently involved.

Crepitus appears to be of considerable significance, when it is present irreversible degenerative change is likely to have taken place, but structural change may occur without crepitus-a result, perhaps, of remodelling of the articular surfaces without cartilage loss and fragmentation.

Table VIII suggests that involvement of the temporomandibular joint by rheumatoid arthritis is not an index of the severity of the systemic manifestations.

Since this paper was presented to the Heberden Society in 1965, rheumatoid arthritis of the temporomandibular joint has been discussed by Marbach and Spiera (1967) in a résumé of two cases which includes general conclusions that cannot be supported. For example, they suggest that in rheumatoid arthritis there is a considerable reduction in the amount of possible condyle movement during mouth opening. Table XI clearly shows that there is only a slight reduction in the amount of opening (as measured between maxillary and mandibular incisors) and mandibular condyle movement which is of little significance.

TABLE XI

FUNCTION OF TEMPOROMANDIBULAR JOINT IN RHEUMATOID ARTHRITIS

Expressed as Degree of Mandibular Condyle Movement measured by Maximum Inter-incisal Opening

\begin{tabular}{|c|c|c|}
\hline \multicolumn{2}{|r|}{ Group } & $\begin{array}{l}\text { Inter-incisal Opening } \\
(\mathrm{mm} .)\end{array}$ \\
\hline \multicolumn{2}{|c|}{$\begin{array}{l}\text { Patients with Rheumatoid Arthritis } \\
\text { of Temporomandibular Joint }\end{array}$} & $38 \cdot 0$ \\
\hline \multirow{3}{*}{ Controls } & A & $43 \cdot 5$ \\
\hline & B & $45 \cdot 0$ \\
\hline & C & $32 \cdot 0$ \\
\hline
\end{tabular}

\section{Functional Aspects}

Amongst the unique characteristics of the temporomandibular joints is the fact that the joint at each end of the mandible is one half of a functional unit. One joint cannot operate independently and therefore any alteration in the activity of one side will affect the other. Clearly a unilateral chewing habit constitutes an uneven distribution of function between the right and left joints. Previous work (Franks, 1967) has indicated that such a habit is of considerable importance in the aetiology of temporomandibular joint pain-dysfunction. The significant incidence of abnormal jaw function amongst rheu matoid patients is striking. 
It would be legitimate to ask which came first, the deranged activity or the joint disease. The results indicate that the patient's awareness of a temporomandibular joint disorder (i.e. history) was not significant in relation to the incidence of radiological change. Furthermore it was found that the average joint movement measured as maximal mouth opening without pain in the rheumatoid patients was reduced but not significantly (Table XI). This would suggest that the functional effect of rheumatoid arthritis on the joint was not significant and that the significant incidence of unilateral chewing was not a result of the joint changes but more probably a precursor.

\section{Summary}

The examination of 100 patients with rheumatoid arthritis has shown that the temporomandibular joint can become involved at varying stages of the natural history of the disease, and that such signs and symptoms are much more common than previous work has suggested. The more severe the manifestations of the general complaint, the more commonly are the temporomandibular joints involved; however, the involvement of these joints is not itself an index of the severity of the systemic manifestations.

Bywaters (1962) posed a fundamental question, "What determines the localization of rheumatoid arthritis in a joint ?", and suggested that movement itself, or perhaps the mild trauma which occurs with movement, may be responsible for the localization of the inflammatory agent. The present study shows that this concept may be applied and extended; the appearance of rheumatoid changes in the temporomandibular joint may be related to an uneven distribution of function between the right and left sides.

I am indebted to the Medical Research Council for their support during the period that the above work was carried out. I should also like to express my thanks to Dr. Oswald Savage, not only for allowing me access to his patients, but for the spirit in which his co-operation was offered. I am also very grateful to Dr. Bernard Watkin for his valuable help and assistance in the systemic assessment of the rheumatoid patients.

\section{REFERENCES}

Blackwood, H. J. J. (1963). Brit. dent. J., 115, 317 (Arthritis of the mandibular joint).

Blanc, P. (1959). Cahiers odontostomat., 9, No. 3-4, p. 17 (L'atteinte de l'articulation temporomaxillaise au cours du rhumatisme inflammatoire chronique).

Bywaters, E. G. L. (1962). "Inflammatory Polyarthritis", in "Conference on the Causes and Treatment of Rheumatic Diseases, 1962," p. 15. (1st Nuffield Conference on Rheumatology.) Nuffield Foundation, London.

Edström, G. (1961). Acta rheum. scand., 7, 151 (Destructions of hip joint in rheumatoid arthritis during long-term steroid therapy).

Einaudi, G., and Viara, M. (1964). Reumatismo, 16, 341 (Il comportamento dell' articolazione temporo-mandibolare nei pazienti affetti da artrite reumatoide).

Franks, A. S. T. (1964). Dent. Practit., 15, 94 (The social character of temporomandibular joint dysfunction).

(1965). J. pros. Dent., 15, 1122 (Masticatory muscle hyperactivity and temporomandibular joint dysfunction).

- (1967). Brit. J. oral Surg., 5, 157 (The dental health of patients presenting with temporomandibular joint dysfunction).

Hankey, G. T. (1963). Brit. dent. J., 115, 324 (Discussion of "Arthritis of the mandibular joint").

Hartfall, S. J., and Wright, V. (1961). "Manifestations of Rheumatoid Arthritis". Reckitt \& Sons, Hull.

Kellgren, J. H., Lawrence, J. S., and Aitken-Swan, J. (1953). Ann. rheum. Dis., 12, 5 (Rheumatic complaints in an urban population).

Marbach, J. J., and Spiera, H. (1967). Ibid., 26, 538 (Rheumatoid arthritis of the temporomandibular joints).

Markowitz, H. A., and Gerry, R. G. (1949). Oral Surg., 2, 1309 (Temporomandibular joint disease).

Mériel, P., Ruffié, R., Cadenat, H., Fournié, A., and Blanc, P. (1960). J. Radiol. Électrol., 41, 105 (Exploration radioclinique de l'articulation temporo-maxillaire).

Ragan, C. (1949). J. Amer. med. Ass., 141, 124 (The general management of rheumatoid arthritis).

Russell, L. A., and Bayles, T. B. (1941). J. Amer. dent. Ass., 28, 533 (The temporomandibular joint in rheumatoid arthritis). 
Simon, G. (1965). "Principles of Bone X-Ray Diagnosis", 2nd ed., p. 168. Butterworths, London.

Steinbrocker, O., Traeger, C. H., and Batterman, R. C. (1949). J. Amer. med. Ass., 140, 659 (Therapeutic criteria in rheumatoid arthritis).

Uotila, E. (1964). Acta odont. scand., 22, Suppl. 39 (The temporomandibular joint in adult rheumatoid arthritis).

\section{L'articulation temporo-maxillaire chez l'adulte atteint de polyarthrite rheumatoïde}

\section{RÉSUMÉ}

L'examen de cent malades atteints de polyarthrite rhumatoïde a demontré que l'articulation temporomaxillaire peut être affectée aux différents stades de la marche normale de la maladie et que ces signes cliniques et ces symptômes sont beaucoup plus communs que les travaux antérieurs avaient suggéré. Plus les manifestations de la maladie en général sont sérieuses plus il est commun de voir les articulations temporo-maxillaires affectées; l'affection de ces articulations n'est pas d'ellemême un indice de la sévérité des manifestations systémiques.

Bywaters (1962) a posé une question fondamentale, 'Que'est-ce qui détermine la localisation de la polyarthrite rhumatoïde dans une articulation?"' et a suggéré que le mouvement lui-même, ou peut-être le traumatisme léger qui a lieu pendant le mouvement, pourrait être responsable de la localisation de l'agent inflammatoire. Cette étude démontre que ce concept peut être appliqué et étendu, l'apparition des changements rhumatoïdes dans l'articulation temporo-maxillaire peut se rapporter à une distribution inégale des fonctions entre le côté droit et le côté gauche.

\section{La articulación temporomaxilar en adultos con poliartritis reumatoide}

\section{SUMARIO}

El examen de 100 pacientes con poliartritis reumatoide ha revelado que la articulación temporomaxilar puede quedar afectada en diferentes etapas del desarrollo normal de la enfermedad, y que tales manifestaciones y síntomas son mucho más comunes que lo que han sugerido trabajos previos. Cuanto más severas las manifestaciones de la enfermedad general, tanto más comunmente afectadas las articulaciones temporomaxilares; no obstante, la complicación de estas articulaciones no es un índice de la severidad de las manifestaciones sistémicas.

Bywaters (1962) planteó una cuestión fundamental: "¿Qué es lo que determina la localización de la poliartritis reumatoide en una articulación?", y sugirió que el propio movimiento o quizá el ligero trauma que ocurre con el movimiento sería tal vez el causante de la localización del agente inflamatorio. Este estudio muestra que el concepto podría ser aplicado y ampliado, y la aparición de cambios reumáticos en la articulación temporomaxilar pudiera ser atribuída a una distribución desigual de las funciones entre los lados derecho e izquierdo. 